ISLAMIC PRESS

IN THE EARLY SOVIET

DAGESTAN AND

THE JOURNAL "MUSLIMS

Shamil Shikhaliev

OF THE SOVIET ORIENT"

shibaliev74@mail.ru

\title{
Shamil Shikhaliev
}

Ph.D. in History, Head of the Oriental Manuscripts

Fund of the Institute of History, Archeology

and Ethnography of the Dagestan Scientific Center,

Russian Academy of Sciences (Makhachkala

An analysis of a number of articles in imperial and early Soviet newspapers and journals, including "Jaridat Dagistan", shows that the theological discussion that existed in Dagestan in manuscript tradition for more than three bundred years migrated to some extent to new press. This applies to some issues of the theory of Islamic law (the problem of taqlid and ijtihad), as well as some practical legal issues in the field of worship (ibada) and in the sphere of social relations (muiamala).

In the late 1960's in Tashkent, the journal "Muslims of the Soviet Orient" was founded, many issues of which were sent to Dagestan in Uzbek (in Arabic script) and in Arabic; various issues of this journal are currently being found in a number of private collections in Dagestan. In many articles the influence of the already established Soviet Oriental scholarly tradition is noticeable. Articles devoted to the theory and practice of Islamic law, to various issues of Muslim theology, are practically absent. An analysis of the articles of this journal and the "Jaridat Dagistan" shows that if the latter was formed and edited exclusively by Dagestani theologians and served as a platform for discussing theological issues, the journal "Muslims of the Soviet Orient" was a Soviet attempt to represent Muslims and showed how they were seen or wanted to be seen by Soviet authority.

Keywords: Soviet Islam, "Jaridat Dagistan", "Muslims of the Soviet Orient", Islamic press in the USSR. 


\section{ИСЛАМСКАЯ ПРЕССА \\ В РАННЕСОВЕТСКОМ \\ ДАГЕСТАНЕ И ЖУРНАЛ \\ «МУСУЛЬМАНЕ \\ СОВЕТСКОГО ВОСТОКА»}

\section{Шамиль Шихалиев \\ shibaliev74@mail.ru}

DOI: http://dx.doi.org/10.24848/islmlg.07.2.04

Анализ ряда статей имперских и раннесоветских газет и журналов, включая издание "Ажаридат Аагистан", показьвает, что в них в некоторой степени перекочевала та богословская дискуссия, которая существовала $b$, Аагестане в рукописной традичии на протяжении более трехсот лет. Это касается некоторьх вопросов теории мусульманского права (проблема таклида и иджтихада), равно как и некоторье практические правовые вопросы В области культа ("ибада) и сфере взаимоотношений между людьми (му'амала).

В коние 1960-х ге. б Ташкенте бил основан журнал «Мусульмане Советского Востока», многие экземплары которого на узбекском (В арабской графике) и на арабском язьке рассьилались ○ Аагестан; разнье номера этого журнала в настоящее время встречаются 6 ряде частньх коллекиий 6 , Аагестане. Во многих статьях ошутимо влияние уже сформировавиейся к тому периоду советской востоковедной академической традичии. Статьи, посьященнье теории и практике мусульманского

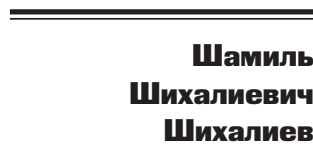

Кандидат исторических наук, заһ. Фондом восточньхх рукописей Института истории, археологии и этнографии Аагестанского научного чентра РАН

(Махачкала) права, разньм вопросам мусульманского богословия, практически отсутствуют. Анализ статей этого журнала и издания "Ажаридат Аагистан» показььвает, ито если последний формировался и редактировался исключительно дагестанскими богословами и служил плошадкой для обсуждения богословских вопросов, то журнал "Мусульмане Советского Востока" явлался советской попьтккой репрезентаиии мусульман и показььал, как видела или хотела видеть их советская власть.

Нлючевые слова: советский ислам, «Ажаридат Аагистан», «Мусульмане Советского Востока», исламская пресса В СССР.

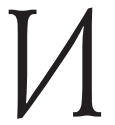

стория арабоязычной прессы в Аагестане насчитывает чуть более ста мет. Первая арабоязычная газета, которая называлась «Ажаридат Аагистан», вышла в свет в 1913 г. в Темир-Хан-Шуре, бывшей столице Аагестанской области, и изАавалась с периодичностью один раз в неделю вплоть до 1919 г‥ САедующий этап развития арабоязычной прессы - это издание мусульманского журнала «Байан ац-хака'ик» в 1925-1928 гг. После 1928 года арабоязычная пресса в Аагестане не издавалась. Вместе с тем в конце 1960-х гг. в Ташкенте был основан журнац «Мусульмане Советского Востока», многие экземпляры которого на узбекском (в арабской графике) и на арабском

1. В начаме 1918 г. эта газета была переименована в «Аагистан». 
языке рассыцацись в Аагестан; разные номера этого журнала в настоящее время встречаются в ряде частных комлекщий в Аагестане.

Несмотря на репрезентацию этих журналов и газет как мусульманских, тем не менее возникает вопрос: насколько в арабоязычной прессе $А$ агестана отражались богословские Аискурсы? Сколько «исламского» было в этих журналах и газетах? Как тематика, стиль, содержание этой прессы отражаци реации изменения эпох - от имперской к советской и насколько она была подвержена вциянию офиџиальной идеологии советского правительства? Конечно же, в условиях господства коммунистической идеологии и жесткого контроля государства над всей советской прессой было бы немыслимо отрицать советскую действительность в мусульманских журналах и газетах. Вместе с тем каким стимем, языком и содержанием советский конструкт был включен в исламскую прессу? Как советский офиџиальный язык публицистики сочетался с исламскими текстами? И кем были авторы статей в этих газетах и журналах? Учитывая, что мегальное исламское образование практически было циквидировано в конце 1920-х гг., но уже в послевоенные годы было вновь восстановцено в рамках медресе Мири Араб, контролируемого советскими чиновниками, было бы мюбопытно обратить внимание на мексику, используемую в статьях этих журналов. Предварительный анализ показывает, что во многих статьях, особенно в журнале «Мусульмане Советского Востока», ощутимо вцияние уже сформировавшейся к тому периоду советской востоковедной академической традиции. Ниже даны некоторые наши гипотезы относительно функџионирования исламской прессы в советском государстве.

Анациз ряда статей этих имперских и раннесоветских газет и журналов показывает, что в них в некоторой степени перекочевала та богословская дискуссия, которая существоваца в Аагестане в рукописной традиџии на протяжении более трехсот мет. Это касается некоторых вопросов теории мусульманского права (проблема таклида и иджти$x a \partial a$ ), равно как и некоторые практические правовые вопросы в области культа ('ибада) и сфере взаимоотношений между мюдьми (му'амала)․․ Вместе с тем в последние годы издания журнала «Байан ац-хака'ик» в стиле и кексике ряда статей ощущается сицьное влияние советских реалий. В журнале же «Мусульмане Советского Востока» статьи, посвященные теории и практике мусульманского права, разным вопросам мусульманского богословия, практически отсутствуют. Анализ статей этих двух журналов показывает, что если первый формировался и реАактировался искиючительно Аагестанскими богословами и служиц площадкой дмя обсуждения богословских вопросов, то журнац «Мусульмане Советского Востока» явцялся советской попыткой репрезентации мусульман и показывал, как видела ици хотела видеть их советская власть.

\section{«ДЖАРИДАТ ДАГИСТАН — П ПЕРВАЯ АРАБОЯЗЫЧНАЯ ГАЗЕТА НА КАВКАЗЕ}

$\mathrm{H}$

ачало издания газеты «Ажаридат Аагистан» совпало по хронологии с широким распространением идей мусульманского реформаторства в Аагестане. Это новое движение было обусловлено тесными контактами дагестанских богословов с Египтом и внутренними мусумьманскими регионами Российской империи, где в конце XIX в. идеи о реформах мусульманского общества были достаточно популярными (Gould, Shikhaliev, 2017a).

2. О правовых дебатах в среде дагестанских богословов см.: Бобровников В.О., Шехагомедов М.Г., Шихалиев Ш.Ш. Мусульманское право и обычай в российском Аагестане: источники и исследования. СПб, 2017 (в печати). 
Связи дагестанских реформаторов с разными регионами обусловици специфику развития реформаторского Авижения в Аагестане 3 . Аагестанские интелмектуалы из числа реформаторов, помимо прочего, выступаци с критикой существующих правовых школ, призывая расширить сферу применения иджтихада, а также выступали с жесткой критикой современных им суфиев и суфизма, представителями которого выступала «старая» Ауховная элита.

Призыв реформаторов к реформе образования, изучению естественных наук, равно как и жесткая критика суфизма, к которому имперская вцасть все еще продоцжала относиться подозрительно, невольно отвечали интересам имперской власти в Аагестане. Воспринимая суфизм как опасное явление, власть рассчитывала заручиться поддержкой определенной части мусульманской элиты. Вероятно, это послужило причиной того, что имперская администрация в миџе генерац-губернатора Аагестанской области Сигизмунда Вольского (1852 - после 1917 г.) выступила с инициативой издания арабоязычной газеты «Ажаридат Аагистан». Издание этой газеты было поручено начальнику канцемярии военного губернатора Аагестанской обцасти Бадави Саидову (1877-1927). ГАавную же работу по изданию этой газеты выполняли Али ал-Гумуки (Каяев, 1878-1943), ключевая фигура реформаторского движения в Аагестане в начале XX в. (Наврузов, 2012, 14). Финансирование этой газеты в 1913-1914 гг. осушествцялось за счет администрации Аагестанской области, которая одновременно с финансированием этой газеты приказама сельским словесным судам подписаться на нее (Наврузов, 2012, 16). Позже она стала издаваться на цичные средства Бадави Саидова, а также при финансовой поддержке владетеля исламской типографии в Темир-Хан-Шуре, промышленника и мецената Мухаммада Мирзы Мавраева.

По своей структуре и тематике обсуждаемых вопросов газета «Ажаридат Аагистан» во многом повторяет известный египетский журнац «ац-Манар», издававшийся египетским реформатором Мухаммадом Рашидом Рида (1865-1935), с которым Али Каяев тесно сотрудничал во время своего пребывания в Каире в 1905-1908 гг. ${ }^{4}$

Газета «Ажаридат Аагистан» состояла из 6 разделов: официальный, неофициальный, митературный, раздел писем, объявления, научный раздел (Наврузов, 2012, 16-23).

Поскольку первоначально газета издавалась за счет средств имперской администрации на Кавказе, вполне естественно, что в официальном разделе этой газеты пубциковамись приказы и распоряжения царской администрации.

Неофициальный раздел был представлен перепечаткой новостей из Аругих российских газет, равно как и новостей, полученных из-за рубежа по телеграфу.

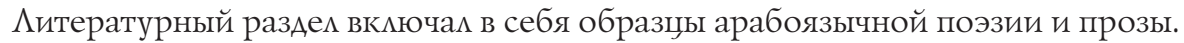

Поскольку газета поддерживала тесную связь с читателями и подписчиками, редактор посчитац нужным отдельно выделить блок переписки с читателями. Таким образом редакция получала сведения о читательской аудитории, географическом распространении газеты. С Аругой стороны, письма в аАрес редакции позволяли реагировать на все нужды и пожелания читателей, что делало газету интересной и популярной.

В следующей рубрике печатались объявления частного характера - о продаже книг, мечебной практике и т.п.

3. Более подробно см.: Шихалиев (2017).

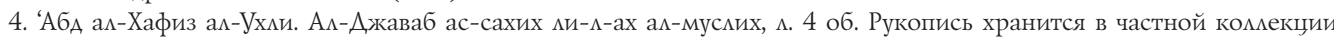
автора. См. также: Шихалиев, 2010, 333. 
Наконец, последний раздел, судя по письмам в редакцию, был наиболее популярным и охватывац широкий спектр вопросов. ОАним из них бымо обсуждение ряда богословских проблем, таких как возможность уплаты закята с бумажных денег, повторение поцуденной молитвы после пятничной, проблема таклида и иджтихада, сущность вакуфной

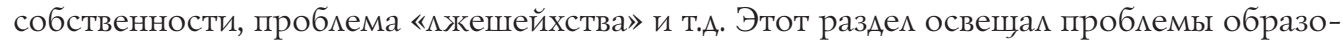
вания и просвещения, роли женщины в дагестанском обществе, а также вопросы естественнонаучного профимя: географии, медиџины, астрономии и т.А.

В целом, последний раздел состоял в основном из тех же тем, которые бурно обсуждались в Аагестане в конце XIX - начале XX вв.5. И как уже отмечалось выше, богословская полемика, ранее обсуждаемая в рукописной традиции, плавно перекочевала на страницы мусульманской прессы. Аоступность газет, широта географии их распространения, низкая стоимость способствоваци значительному расширению читательской аудитории, что в последующем Аало толчок еще более бурному обсуждению религиозных и социальных вопросов.

Имперская администрация, издавая газету, использовала ее в качестве площадки Аля критики преАставителей «старой» Ауховной элиты с џелью уменьшения их влияния на население.

Вместе с тем сами реформаторы не быми активными сторонниками имперской вмасти, о чем свидетельствуют письменные источники. ОАним из главных вопросов, которые поднимали реформаторы, была реформа системы исламского образования и выбор языка обучения в Аагестанских мадраса. Наиболее активные ученые из числа реформаторов - Али Каяев и Абусуфьян Акаев в середине 1917 года критиковали языковую политику Российской империи, отмечая, что эта политика посредством открытия русских школ в Аагестане была направлена на «русификацию народов Аагестана, отрыв дагестанцев от своих корней» (А^-Гумуки, 1917; Акаев, 1992; Каяев, 1993). Предостерегая от обучения в русских школах, Али Каяев и Абусуфьян Акаев предлагали одинаковую модель мусульманской школы, где обучение велось бы на местных дагестанских языках 6 .

В данном контексте мы имеем дело не с тем, что реформаторы были активными сторонниками имперской вцасти, скорее они были за взаимовыгодное сотрудничество новой мусульманской элиты и имперской вмасти. В условиях подавцяющего перевеса и авторитета среди мусульман Аагестана сторонников шафиитской правовой системы и последователей суфизма реформаторам была нужна платформа Аля развития своих идей, роль которой играла газета «Ажаридат Аагистан», также они нужАацись в поАдержке со стороны имперской власти. В свою очередь имперские чиновники пытались использовать идеи реформаторов (с их критикой суфизма и традиционных мусульманских правовых школ) в своих интересах.

Таким образом, газета была преимущественно ориентирована на развитие идей мусульманского реформаторства, однако Аругая часть мусульманской элиты, преАставленной противниками реформ в области богословия, в том числе суфиями, против которых выступала газета, имела в Аагестане значительный вес. Надежды имперской власти на развитие идей реформаторства с целью подорвать влияние на население основной части мусульманской элиты, к которой вмасть продолжала относиться с подозрением, не оправдались. ИАеи мусульманского реформаторства в имперский период не распро-

5. Более подробно об этом см.: Gould, Shikhaliev (2017b).

6. Более подробно об этом см.: Kemper, Shikhaliev (2015). 
странились в Аагестане так широко, как это было в мусульманском Закавказье, Крыму и Волго-Уральском регионе. Вероятно, поэтому имперская власть потеряла интерес к этой газете и уже в 1914 г. перестала ее финансировать. Вместе с тем обозначенные в этой газете идеи реформы системы исламского образования, необходимость более широкого развития наук, особенно естественнонаучного профиля, критика суфизма были интересны в последующем советской власти, которая, по примеру имперской, также инициироваца издание мусульманского журнала «Байан ац-хака’ик».

\section{ОТ БОГОСЛОВСКИХ ДЕБАТОВ К СОВЕТСКИМ РЕАЛИЯМ?}

$\Pi$

осле установления советской власти в Аагестане в 1919 г. большевики проводили свою политику в отношении ислама исходя из тех же целей и заАач, что и имперская власть. Эта политика была направлена на расширение существующих противоречий внутри мусульманской элиты Аагестана.

В событиях периода Гражданской войны в Аагестане соџиалистам удалось привлечь на свою сторону часть представителей местной духовной элиты (кадиев, суфийских шейхов, богословов), фактически расколов элиту на две частит. Затем, после подавления в 1921 г. антисоветского восстания, которое было организованно частью элиты, выступавшей с идеями независимости Кавказа, советская власть начала проводить политику постепенного уменьшения вцияния мусульманской элиты на насемение.

Поскольку в Аагестане представители «старой» Ауховной элиты, подАержавшей советскую власть (богословы, кадии, суфийские шейхи) все еще продолжали пользоваться авторитетом и вциянием на население, соџиалисты делали ставку на реформаторов, идеи которых во многом отвечаци интересам большевиков.

Таким образом, вначале большевики раскололи представителей местной, «традиционной» Ауховной элиты на Аве части, противопоставив их Аруг Аругу, затем, уничтожив оАну из них, соџиалисты противопоставили оставшейся части этой же элиты реформаторов, разрешив им издавать собственный арабоязычный журнац «Байан ац-хака'ик» и ничем не ограничивая их деятельность.

Как отмечает А.Ю. Арапов, вся работа органов советской вцасти была рассчитана на расширение противоречий между реформаторами, именуемыми в советских документах «прогрессистами», с одной стороны, и «традиџионалистами» с Аругой. Умело используя одних против Аругих, чекисты быстро освоили приемы и методы охранной службы империи и активно их использовали в мусульманском вопросе (Арапов, 2010, 193). Об этом, в частности, свидетельствует «Записка Восточного отдела ОГПУ «О мерах борьбы с мусауховенством», октябрь 1926 г.», где руководящим органам в регионах предписывается «раздвигать щели между прогрессистами и консерваторами и по минии применения массовых репрессивных мер против реакщии. Последнее особо важно в усмовиях Северного Кавказа (Аагестана)» (Арапов, 2010, 92).

Именно этим предписанием можно объяснить тот факт, что советская вцасть, по примеру имперских властей, в 1925 г. разрешила издание мусульманского журнала «Байан ал-хака' ик». К сожалению, в настоящее время сложно сказать, от кого исходица идея издания этого журнала. Вместе с тем содержание статей прямо свидетельствует о том, что они были направлены против ряда норм и положений, которые были широко

7. Более подробно см.: Сулаев (2009). 
популярны среди представителей «старой» элиты. Это касается, прежде всего, вопроса мегитимности суфизма и суфиев, а также призывов к более широкому применению практики иджтихада.

Отличие газеты «Ажаридат Аагистан» и журнала «Байан ац-хака'ик» состоит в том, что в последнем практически не издавались официальные распоряжения новой власти. Вместе с тем содержание и тематика богословских статей в этих двух изданиях поразительно схожи.

Здесь уместно отметить тот факт, что авторы газеты «Ажаридат Аагистан» практически не представлены в журнале «Байан ац-хака' ик», несмотря на то, что эти издания хронологически разделяло не более десяти мет. В частности, главный редактор «Ажаридат Аагистан» Али Каяев не написал ни одной статьи в «Байан ац-хака'ик». В свою очередь, главный редактор журнала Абусуфьян Акаев ранее издал всего несколько статей в газете «Ажаридат Аагистан». Учитывая то, что она печаталась большим тиражом и было издано более 250 номеров, а также пубцикационную активность Абусуфьяна Акаева, который в эти же годы изАал большое количество книг в местной типографии, такая пубцикационная пассивность в газете обращает на себя внимание. То же самое можно сказать и об остальных авторах статей в газете «Ажаридат Аагистан» и журнале «Байан ал-хака'ик». Несмотря на то, что авторы газеты и журнала имели общие взгляды на развитие мусульманского общества, были современниками и часто общались Аруг с Аругом, такое взаимное игнорирование в прессе выглядит несколько странно.

Первый номер журнала «Байан ац-хака'ик» вышел в сентябре 1925 года. По замыслу редакторов, издание было направлено на «разъяснение достоинств ислама, выявление истины и очищение шариата от вредоносных новшеств и домыслов» (Байан ал-хака' ик, 1925, 1). Всего бымо издано 12 номеров журнала, которые выходици с разной периодичностью вплоть до 1928 г. Последний, двенадџатый номер этого журнала не быц завершен, половина страниц этого журнала осталась пустой. В 1928 г. советская власть начала проводить ряд мер по усилению антирелигиозной кампании: было миквидировано мегальное исламское образование, шариатские суды были закрыты, вакуфные земли мечетей и медресе передавались крестьянским комитетам. Аетом 1929 г. советская власть циквидироваяа местную организацию «Аини Комитет», которая, по мнению властей, готовила антисоветское восстание в Аагестане. Все чиены редкомлегии журнала «Байан ац-хака'ик», которые входили в состав «Аини Комитет», были репрессированы: главный редактор журнала Абусуфьян Акаев был сослан в Котласские магеря, остальные чиены редколмегии были расстреляны в 1929 г.

Журнал быц посвящен в основном таким вопросам, как суфизм и мжешейхи, развитие и реформа системы мусульманского образования, а также некоторые правовые вопросы: таклид и иджтихад и граниџы их допустимости; трехкратная проџеАура развода; дозволенность изображения Аюдей и пр.

Стиль мексики и тематика статей практически не отличацись от аналогичных работ, написанных в рамках мусульманской дискуссии. В частности, правовая полемика, отраженная в многочисленных рукописных сочинениях позднего имперского и раннего советского периода, практически полностью перешла на страницы этого журнала. По своему стилю, символам, тематике, образам, методологии и ссылкам на мусульманские источники богословские статьи в журнале «Байан ац-хака'ик» и многочисленных рукописных полемических правовых сочинений практически не отличаются Аруг от Аруга. 
Можно сказать, что полемические или правовые работы в рамках исламского дискурса, которые были широко распространены в дагестанской рукописной традиции, плавно переместились на страниџы журнала «Байан ац-хака'ик».

Вместе с тем следует отметить, что тематика и стиль изложения статей ближе к послеАним номерам журнала несколько менялись от сугубо исламских сюжетов (теория и практика мусульманского права, суфизм, мусульманская этика и догматика) к советским. Причем по мере издания последующих номеров журнала этот «советский конструкт» проявцяется все чаще и влияние советской действительности выражается все яснее.

К примеру, в 1927 году, за год до закрытия журнала, была опубцикована статья о мусульманском съезде в Адыгее. В статье часто встречается мексика, популярная в работах советских востоковедов более позднего периода. Вот, в частности, как отражается в тексте советская действительность 1920-х годов

«От редакции: В декабре 1925 года мусульмане Черкесии в Советской Республике Адьиея созвали всеобиий мусульманский сәезд для решения некоторьх религиозньх вопросоһ. После окончания сәезда они написали на арабском язьке то, что обсуждалось на съезде, и послали это письмо 6 нашу редакиию. Мь прочитали его и вьюразили им благодарность за созььв этого сәезда и решение поставленньх вопросов. Мьь решили опубликовать две темьи, касатошиеся этого сәезда: вводную часть, и те вопрось, по которьм они приняли решения. Ниже мь публикуем это письмо.

Мусульманский сбезд в Адьиее. Ислам - древняя религия, и 8 течение периода его распространения вплоть до сегодняшнего дня в нем произошли разнье изменения. За это время бьли привнесень в ислам новшества (البدعة) и искажения (الخر افات), которье не дозволяли Аллах и Его посланник. Эти новиества были введеньк как в сферу поведения и взаимоотношения людей (му'амалат), таки в область культа ("ибадат). Удивительно, что, исказив нормь Корана в области культа ("ибада), они усложнили его, привнося новшества, которье запрещает Аллах. Можно было би еше понять, если бь они облегчии эти нормь!! Колониальные деспотичные государства (الدول الاستعمارية الاستبدادية), такие как Англия, Франиия, Россия и некоторье мусульманские государства (ملوك) соر) содйствовали искажению Слова Аллаха, так как это способствовало интересам империалистических (колониальньх) государств (الدول الاستعمارية). Эти государства хотели ослабить группу людей с тем, чтобь иметь пользу отних. Законь справедливости, равенства и братства (العدالة و المساوة و الإخوة), которье запрещатот захват имущества путем обмана и которьми руководствовались люди, бьли искажень и заменень другими, где возвеличивают богатьхх и унижают бедньх. Это привело к тому, что, как на сегодняиний день очебидно, слабье народь попали в когти сильньх народов. Эти искажения законов также способстьовали тому, что правители этих стран накопили в своих руках огромныле богатства.

Точно также, путем подобньх изменений в исламе деспотичные государства Востока (الدول الاستبدادية الثرقية), их кадии и шейхи также изблекли для себя бьигоу. [Это продолжалось] до тех пор, пока не появился в пятом веке хиджрь имам ал-Газали ${ }^{11}$, ии-

8. 3Аесь и далее некоторые характерные фрагменты текста выделены нами.

9. Имеется в виду Российская империя.

10. Аюбопытно, что несколько другая форма, а именно «свобода, равенство и братство» является мозунгом Французской революции, который часто использовали большевики.

11. Известный мусульманский правовед и мистик Абу Хамид Мухаммад ал-Газали (1058-1111). 
роко известньй 8 Египте, Аамаске, Багдаде и $в$ других мусульманских городах. Он начал вьступать против этих искажении, опровергая их очевидньми доводами (Корана и Суннь). После смерти ал-Газали, его многочисленнье ученики с большим усердием продолжили его деятельность. На своем пути распространения истинь они столкнулись с многочисленньми трудностами и сопротивлением правителей этих деспотичньх стран (الدول الاستبدادية). Ислам среди черкесских народов Северного Кабказа начал распространаться посредстьом путешественников из разньх мусульманских стран ८ 1717 году. Кавказские народь (В данном случае, мусульмане иентрального и западного Кавказа. - Ш.Ш.) следовали религии, которая пришла кним из Туриии, равно как приили к ним некоторье нормь шариата без их анализа соответствия Сунне. И это продолжалось вплоть до 1907 года. Затем в 1907 г. ученье Кабказа (иентрального и западно го Кавказа. - Ш.Ш.) решили установить нормьь религии [с точки зрения соответствия норм шариата Корану и Сунне], чтобь отделить истину от лжи. С этой целью они отправихись в Туриито и Египет, чтобь получить там знания, не довольствуясь теми знаниями, которьмм обучали в кавказских мадраса. Когда же эти ученьье [обучабшиеся в Туриии и Египте] узнали истинньий ислам, они начали следовать ему. Тем самьм, ученьье черкесских народов разделились надве группьи, каждая из которьх считала, что только она следует истине, и руководствуется тем, ито изложено в Коране. Группа джадидов (الفر قة الجديدة) начала открыто проповедовать истину. Однако, черкесские объгаи (العادة), которье бьли тесно переплетень с религией, препятствовали им

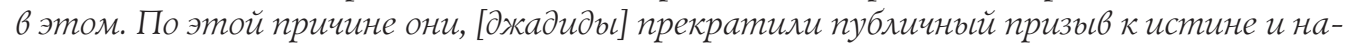
чали распространять сьои идеи постепенно. Они начали распространять истину12 только среди определенного круга людей, которье стремились к этому. Однако, эта партия салафитов-прогрессистов (حزب السلف يرو غريسيت) не достигла своих целей, так как другая группа - группа кадимито (الفر قة القديمة) поддерживалась деспотичным императором (الملك المستبد), ханами и пашами, и одерживала верх.

Они, [император, ханьи, паши] не только не обращали на группу джадидов никакого внимания, но инапротия, насмехались над ней'1. Ирелигиознье спорь между этими двумя группами продолжались весь этот период вплоть до 1920 г., причем победа в этих спорах доставалась больиинству - как правихо, группе «кадимитов» (القديمة). В этом [1920] году установилась новая советская власть (الحكو مة الجديدة الثورية إساويتسكى ولاست)

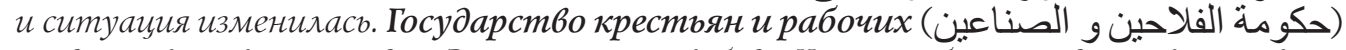
предоставила Всем народам России полную сбободу. Черкесии была предоставлена автономия (ئه فتونوم) и им бьло дано разрешение самостоятельно решать свои дела так, как они хотят. Среди прочего, им бъла предоставлена свобода религии. Однако религия не должна Вмешиваться 8 политику. С распространением света свободьь, 6 том числе 6 религии, группа джадидов (الجديدية) вььвинула своих руководителей и, несмотря на противостояние [кадимитов], начала распространять истину религи Мухаммада, чистую от нововведений, и призьљать к объединению и обсуждению религиозньх вопросов.

В 1922 году ученье и имамь Адьгеи собирались по этому важному вопросу три раза. И 4 декабря 1925 года они вновь собрались с тем, итобь прийти кединому мнению от-

12. Вероятно, речь идет о реформах в области исламского образования и фикха - то, что явцялось основной идеей реформаторов.

13. То есть в данном контексте смысл заключается в том, что старое имперское правительство и местная аристократия не подАерживали идеи джадидов в центральном и западном Кавказе. Это можно объяснить тем, что отношение имперской власти к представителям духовной элиты в центральном и западном Кавказе было более мояльным, чем на восточном, территория которого долгое время была охвачена войной с Российской империей. 
носительно истинь в религиозих вопросах, чтобь больше не осталось противоречий. В этой четвертой встрече проявился фанатизм (تعصّّب) среди представителей кадимитов, которье присутствовали на сәезде, и [стало очебидньм] искажение ими ислама. В этом могли воочио убедиться все, кто присутстьовал на этом собрании.

В этом журнале (будут издань) принятьле на этом собрании решения ${ }^{14}$, напрабленнье на освобождение от когтей таклида и прекрашение привнесения в религю вредоносньх новиеств (البدعة), а также наставление людей на путь истинь В соответствие с Кораном и Сунной» (А^-Ажам“иййа аА-диниййа ..., 14-16).

В этом тексте обращают на себя внимание несколько сюжетов. Первый из них - это наличие в тексте большого количества оборотов, присущих публиџистическому стилю советских журналов и газет, со свойственным им набором идеологических кцише; в мусульманской традиџии, в том числе в предыдущих статьях журнала, такие обороты, как «колониальные деспотичные государства», «империализм», «справедливость, равенство и братство», «партия прогрессистов» и Ар., практически полностью отсутствуют.

Второй момент - это попытка объяснить историческое развитие ислама сквозь марксистскую парадигму развития общественно-экономических формаций и конструирование модели ислама согласно этой парадигме, где «кадимиты» - это сторонники «Аеспотичной имперской власти», тогда как «Ажадиды» - выразители интересов угнетаемого насемения.

Стиль этой статьи также резко отличается от традиционного жанра исламского Аискурса, широко популярного в Аагестане в этот период. Резкое отличие стиця, обилие «советской» цексики дают основание предположить, что данная статья была написана под сильным влиянием советской востоковедной академической школы. Обращает на себя внимание также влияние Ажадидской реформированной системы алфавита на арабоязычный текст. Так, некоторые русские слова в тексте почему-то были написаны арабскими буквами, хоть и имеют арабские словарные эквиваленты (прогрессист, $\boldsymbol{a b}$ тономия - يرو غريسيت , ئه فتونوم), причем они написаны согласно новой орфографии, характерной дмя арабографических работ 1920-х годов.

Таким образом, в журнале можно наблюдать постепенный переход от исламской тематики к политическим вопросам и сращивание исламского и советского дискурсов. Ближе к последним номерам можно заметить постепенный переход от исламских сюжетов к апологии советской вмасти и ее внешней политики.

\section{ЖУРНАЛ ДЛЯ СОВЕТСКИХ МУСУЛЬМАН}

урнал «Мусульмане Советского Востока» издавался в Ташкенте под патронажем СААУМ с 1968 по конец 1980-х гг. вначале на двух (арабском и узбекском), затем на шести (арабском, персидском, узбекском, дари, французском, английском) языках.

Сложно сказать, как именно журнал появцялся на территории Аагестана. Можно преАположить, что рассылка осуществлялась на уровне официальных исламских институтов СССР - СААУМ и АУМСК. РяА номеров журнала можно встретить в Аагестане в частных колмекщиях тех миџ, которые в советский период именовацись «официальными служителями культа» - чиены духовных управлений, а также имамы и муаззины

14. Решения этого съезда изданы в следующем, девятом номере журнала. 
официально зарегистрированных в Аагестане мечетей. Сама реАакция обозначала этот журнац как «религиозный». Вместе с тем наш анализ ровно ста статей этого журнала выявиц следующую картину ${ }^{15}$.

В журнале практически отсутствуют статьи по проблемам мусульманского права, хадисоведения, суфизма, которые встречались в газете «Ажаридат Аагистан» и журнале «Байан ал-хака'ик». В подавцяющем большинстве статьи посвящены критике западного империализма, успехам СССР в различных отраслях народного хозяйства; юбилейные статьи, посвященные тем или иным мусульманским ученым, международным конференциям, широко проводимым СААУМ в 1960-е - 1980-е гг.

В количественном отношении эти статьи можно распределить слеАующим образом:

- Успехи СССР в области сельского хозяйства и промышиенности; критика Израимя и США - 26 статей.

- История и культура ислама: описание городов, мечетей и мавзолеев мусульманских регионов СССР - 17 статей.

- Юбилейные статьи, посвященные видным мусульманским ученым (Алишер Навои, Абу Райхан ац-Бируни, ац-Хорезми и Ар.), - 13 статей.

- Международные конференции, проводимые СААУМ, - 11 статей, плюс три полных номера с текстами докцадов (44 статьи с текстами докладов).

- Международные делегации в республиках Средней Азии - 9 статей.

- Биографии мусульманских ученых - 8 статей.

- Статьи, посвященные мусульманской этике, - 7 статей.

- Статьи, посвященные исламским праздникам ('uд ал-фuтр, 'uд ал-адха), 3 статьи.

- Паломничество мусульман СССР - 3 статьи.

- Издание Корана и мусульманских календарей - 2 статьи.

- Заметка об исламском образовании в Узбекской ССР - 1 статья

- Богословские статьи (фикх, хадисоведение, суфизм, 'акида) - 0 статей.

Краткий анализ этих блоков показывает следующую картину:

Успехи СССР в области сельского хозяйства и промышиенности. Эти статьи в основном посвящены развитию промышиенности, сельского хозяйства в респубциках Средней Азии, Поволжья и Кавказа в контексте того, что дала советская власть мусульманам СССР в области развития образования, зАравоохранения, культуры, промышиенности и сельского хозяйства ${ }^{16}$. Практически во всех этих статьях дается сравнительная характеристика промышкенности и сельского хозяйства «до и после Октябрьской революции». ГАавная мысль статей: в имперский период «мусульманские народы Востока» жили плохо, отставаци в промышленном развитии; у них отсутствоваца развитая система зАравоохранения и образования; они не имели своей наџиональной истории. После советской вцасти все эти отрасли начаци стремительно развиваться. В контексте этого вытекает соответствующий вывоА, что соџиализм - это более прогрессивный, по сравнению с империа-

15. Статьи в этом журнале были выбраны нами не в результате специального отбора, а последовательно, начиная с первого номера.

16. Мусульмане Советского Востока, 1969, № 2, с. 11-13; 1969, № 3, с. 31-32; 1969, № 4, с. 27-29; 1971, № 9-10, с. 22-27; 1972, № 11, c. 29-30; 1973, № 17, c. 2-3, 16-18; 1974, № 21, c. 13-18, 27-30; 1975, № 26, c. 21-23. 
Аизмом, общественный строй. И успехи советской власти в развитии народного хозяйства, отраженные в этом журнале, должны быть ярким свидетельством истинности тезиса о смене общественно-экономических формаџий и о негативной сущности империализма.

Раздел «История и культура». В этом тематическом блоке содержатся в основном статьи, посвященные культурному развитию мусульманских регионов СССР. Причем, как и в предыдущем бцоке, культура и историческое развитие мусульманских регионов СССР рассматриваются сквозь ярко выраженный хронологический разрез: до и после Октябрьской революции.

В частности, в этом блоке рассматриваются история и культура союзных республик Средней Азии, а также автономных республик Поволжья и Кавказа, крупных городов Средней Азии, таких как Ташкент, Самарканд и т.А. Основное внимание удемяется критике имперского периода в истории этих регионов и демонстраџии положительного обцика советской власти, которая предоставица мусульманам этих регионов возможность развивать свою наџиональную историю и культуру. Примечательно, что и история, и культура рассматриваются в журнале сквозь призму национальностей, совпадающих с административными границами республик: Узбекская ССР и узбеки; Таджикская ССР и таджики, Башкирская АССР и башкиры, Казахская ССР и казахи, Азербайджанская ССР и азербайджанџы и т.А. Так, в частности, в статье «Башкиры в прошлом и настояшем» история башкир описывается в контексте создания Башкирской АССР 23 марта 1919 г., причем татары, проживающие в Башкирии, не упоминаются, так что история башкир полностью накцадывается на административную территорию Башкирской АССР 17.

Практически во всех этих статьях, посвященных культурному развитию этих респуб-

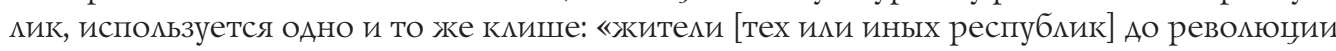
в подавляющем большинстве были неграмотными. Сейчас же, в годы советской власти [эти республики], развиваются, опережкая в вопросах высшего образования многие страны Запада» ${ }^{18}$.

В статьях этого раздела очень часто используется термин «куиьтура» (الثقافة), а также словосочетание общественное и культурное развитие (التطور الاجتماعي و الثقافى). Структура, стиль, содержание этих статей иногда подсознательно, а зачастую и прямо формируют у читателей мысль о том, что ислам - это прежде всего культура и история (сооружение памятников архитектуры - мавзолеев, мечетей), а вовсе не богословская составцяющая деятельности тех, кто, собственно, похоронен в этих мавзолеях.

Второй момент, который обращает на себя внимание, это противопоставление имперской власти (со знаком минус) и советской власти (в положительном аспекте), причем в статьях журнала отмечается, что советская власть предоставила больше свобоА в национальном самоопределении мусульман СССР.

Юбилейные статьи в основном посвящены годовщине со Аня рождения или смерти разных миц, как мусульманских, так и советских деятелей. Само по себе празднование юбилеев - это типично советский конструкт, так как в мусульманской практике нет такой традиции. Настоящая жизнь в мусульманской традиции начинается после смерти, а все, что было до смерти, начиная с рождения человека,- это всего мишь время, данное мусульманину для подготовки к потусторонней вечной жизни. Не случайно, что на ран-

17. Ал-БашкурА кадиман ва хадисан (Башкиры в прошиом и настоящем) // Мусульмане Советского Востока, 1973, № 17, c. 16.

18. Мусульмане Советского Востока, 1969, № 4, с. 27-29; 1973, № 17, с. 2-3, с. 16-18. 
них надмогильных памятниках и в мусульманской митературе в целом (за исключением, пожалуй, библиографических словарей) даты рождения зачастую игнорируются и практически всегда пишутся даты смерти тех или иных миџ (Шихсаидов, 1984).

Международные делегации, конференции, борьба за мир, критика Израиля и США. В статьях этого раздела представлена внешняя и внутренняя политика СССР. Практически все статьи этого раздела затрагивают два главных вопроса: Советский Союз как гарант мира, а капитацистические страны как агрессоры. Эта дихотомия преАставлена сквозь призму марксистской парадигмы о смене экономических формаций. Суть этого посыла - показать агрессивную сущность империацизма, противопоставить сощиалистический строй как более развитый и прогрессивный по сравнению с империализмом. Такая риторика выделяется во многих статьях журнала в следующих тезисах.

Раньше мусульмане Советского Востока жили плохо, отставаци в экономическом, культурном и историческом развитии в силу того, что жили в более регрессивных формаџиях, где была частная собственность (земля, фабрики, заводы, водные ресурсы принадлежали капитацистам и помещикам) и экспцуатация трудового народа (труженики мусульманского Востока - крестьяне и рабочие - работали на помещиков и капитацистов). Ислам у мусульманских народов Востока при капитацистическом строе тоже был «неправицьный», потому что мусульманская духовная элита поддерживала такой «неправильный» и «ущербный» с точки зрения марксизма строй. Капитацизм и империализм как последнюю стадию развития капитацизма отличает агрессивная политика, что Аюди всего мира могут наблюдать на примере израильской и американской агрессии по отношению к странам Бцижнего Востока (Израиль и арабо-израильские войны) и Юго-Восточной Азии (Ааос, Вьетнам, Кампучия). Эта агрессия явмяется стремлением империалистического Запада к «закабалению, угнетению и эксплуатации трудового, свободного арабского населения». Соџиализм же, как более прогрессивный строй, борется за защиту прав эксплуатируемого населения, за предоставление свобод всем, независимо от их расовой, национальной или религиозной принадлежности.

Статьи о международных исламских конференциях с участием представителей мусульманской элиты из зарубежжных стран должны были наглядно подтвердить тезис о прогрессивной форме социалистического строя. Неслучайно представителей арабских делегаций водили не только по многочисленным музеям, мавзолеям, но также и по крупным промышленным объектам, с тем чтобы наглядно продемонстрировать успехи СССР в промышленности и сельском хозяйстве.

Если сгруппировать условную тематику статей в этом журнале в проџентном соотношении, то статистика будет выглядеть следующим образом: международные делегации и конференции, политические вопросы, в том числе критика стран Запада и Израиля - 59\%; биографии мусульманских ученых (в контексте «культурного наследия мусульман») - 25\%; вопросы мусульманской этики - 7\%; исламские праздники и обряды - 6\%; исламское образование и митература - 3\%; вопросы исламского богословского комплекса (право, догматика) - 0\%.

Обращает на себя внимание, что в журнале нет ни одной статьи, посвященной вопросам теории ици практики мусульманского права Аибо вопросам догматики. Можно отметить резкое отличие тематики статей журнала «Мусульмане Советского Востока» по сравнению с рассмотренной выше мусульманской прессой Аагестана, где в подавцяющем большинстве были представлены вопросы мусульманского права и догматики. 
Вместе с тем исследователь Б.М. Бабаджанов отмечает, что в архиве уполномоченного по делам религий Узбекской ССР находится большое количество статей, посвященных богословским вопросам, которые были представлены в реАакцию журнала «Мусульмане Советского Востока», но не были опубцикованы ${ }^{19}$.

Текстологический анализ статей журнала «Мусульмане Советского Востока» позвомяет говорить о том, что в статьях этого журнаца широко использованы стиль, символы, образы, содержание и даже иексика, характерная для советской академической востоковедной школы, и практически полностью отсутствует богословская дискуссия. По своему стилю статьи в журнале резко отличаются от Аосоветской или раннесоветской Аагестанской мусульманской прессы, в которой, как уже было сказано выше, практически отсутствуют идеологические клише. Ааже ицлюстрации в журнале подобраны таким образом, чтобы подчеркнуть некую репрезентативность советского мусульманина, вооруженного «современными знаниями», а также успехи СССР в области промышиенности и сельского хозяйства. Фотографии этого журнала показывают репрезентацию ислама в СССР в контексте местных наџиональных культур.

Если говорить о мексике, употребцяемой в журнале, то она часто представцяет собой кальку с советских идеологических кцише. Так, в статьях журнала довольно часто встречаются следующие слова и термины: «мусульманское духовенство» (Аословно: мусульманские мюди религии / мусульманские священноскужители - رجال الدين الاسلامى); «фашистская диктатура» (الدكتاتورية الفاشية); «изнемогают под оковами империализма» (رزح تحت النير الاستعماري); «непрекращающаяся борьба с империалистическими угне-

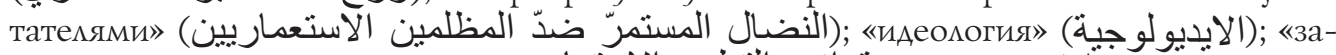

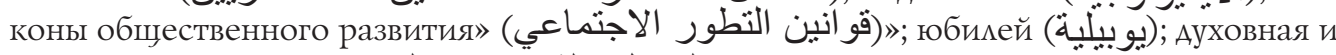
культурная сфера (المجال الثقافى و الروحيى); мусульманские советские республики u Ap.

Подобное же мы можем наблюдать и в количестве исламской цексики в текстах. Характерно в этом отношении выступление муфтия АУМСК М.-Х. Курбанова, опубцикованное в оАном из номеров:

«Мусульмане Северного Кавказа - это единая советская семья, равная в религиозньх делах и в общественной жизни. Мусульмане Северного Кавказа активно участвуют в общественной жизни странь, б строительстве лучшего общества. Они работатот на заводах и фабриках, на полях, 6 учреждениях науки и культурь. Школь, а также вььсие и средние учебнье заведения переполнень учашимися из числа коренньх народов. Сегодня мусульмане Северного Кабказа, благодаря неустанной заботе советского государстьа достигли вьсот в разньх сферах деятельности: в области науки и образования, экономики, сочиальной жизни, опережая тем самьми многие отсталье странь Европьь. Мусульмане Северного Кавказа живут в безопасности под сенью мирной политики Советского государства. Каждое мгновение они готовь оказать любую поддержку народу б строительстве свободного общества, а также готовы бороться с любьм внешним врагом»².

В Аанном фрагменте текста ислам занимает всего мишь небольшое место от всего текста и воплощен всего иишь в одном слове - «мусульмане». Если же сочетание «мусульмане Северного Кавказа» заменить Аюбой Аругой фразой, например «граждане СССР» или «рабочие и крестьяне», то от исламской тематики в Аанном тексте ничего

19. Устная беседа с Б.М. Бабаджановым, Санкт-Петербург, 21 апреля 2016 г.

20. Мухаммад-хаджи Курбанов. Мусульмане Северного Кавказа // Мусульмане Советского Востока, 1969, № 2, с. 20. 


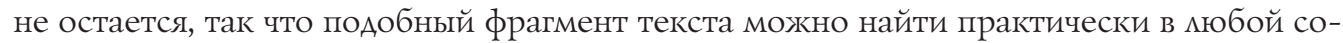
ветской газете.

Аругой яркий пример сильного влияния советской идеологии можно наблюдать в выступлении М.-Х. Курбанова на международной конференции в Ташкенте в 1970 г. Сквозь призму марксистского учения об общественно-экономических формациях статья подтверждает тезис В.И. Аенина об агрессивной политике империализма. В контексте этого М.-Х. Курбанов критикует агрессию США и Израиця против арабских стран и стран Юго-Восточной Азии:

«Израильские агрессорь и те, кто им покровительствует, следуют по пути террора, угроз, эскалачии враждь и унижения боли арабского народа... Американские империалисть и их марионетки (الصنيعة) не прекращают попьгтки установить свою власть над гражданами свободньх, независимьх стран, таких как Вьетнам, Кампучия, Ааос... Результатом империалистической политики [европейских стран] является то, что мусульмане стали изолированьь, так ито не знали о положении друг друга в разньх областах исламского мира. Заботу же о мусульманах проявляет только Советское правительство и другие сочиалистические страньи, за что мь благодарим их»²1.

Аюбопытно, что в качестве обоснования необходимости арабского сопротивления Израилю Мухаммад-хаджи Курбанов приводит айат Корана, который в постсоветской России часто используется различного рода радикалами в качестве довода о необходимости джихада против существующей власти: «Сражайтесь на пути Аллаха с теми, кто сражается против вас, но не преступайте [границ дозволенного]. Воистину, Аллах не любит преступающих [гранииы]. Убивайте [неверуюших], где бь вы их ни встретили, изгониите их из тех мест, откуда они вас изгнали» (Коран, 2:190-191).

В целом, в журнале «Мусульмане Советского Востока» содержится довольно много статей, которые затрагивают внешнеполитические вопросы. Причем многие статьи посвящены критике внешней политики Израиця и США по отношению к странам Ближнего Востока и Юго-Восточной Азии. Многие статьи мусульманских мидеров СССР по сути повторяют офиџиальную риторику советского государства об «агрессивной сущности империацизма». Так, муфтий АУМСК М.-Х. Курбанов опубциковац в оАном из номеров журнала статью, где говорится следуюшее: «Соединеннье Штать Америки сделали ставку насионизм - экстремистскую иовинистическую организачию

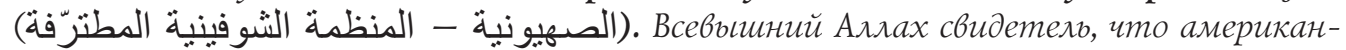
ский империализм играет в этих собьтиях роль подстрекателя. Очевидна всему миру постьцная роль сущности империалистической агрессии проти стран арабского Востока... Фашистская диктатура (الدكتاتورية الفاثية) стала идеологией (الايديولوجية) правяших кругов Израиля, которая является марионеткой США и осуществляет своюо агрессивную политику по отношению к мусульманам» ${ }^{22}$.

Схожий по своему содержанию текст был озвучен ранее $\Lambda . И$. Брежневым: «Аейстбия США, Англии и ФРГ, занявиих позииит поошрения агрессии своих марионеток - правителей Израиля против соседних арабских государсть, еше раз раскрьли перед народами коварную сущность политики империалистов и вьзвали возмущение всех прогрессивньх

21. Мухаммад-хаджи Курбанов. Ал-Кифах дидАа 'удван ал-имбирийали фи аш-шарк ал-'араби ва Ажунуб шарк асийа (Борьба против империалистической агрессии на арабском Востоке и Юго-Восточной Азии) // Мусульмане Советского Востока, 1971, № 9-10, с. 5-6.

22. Мухаммад-хаджи Курбанов. Ал-Кифах дидАа 'удван ал-имбирийали фи аш-шарк ал-'араби ва Ажунуб шарк асийа // Мусульмане Советского Востока, № 9-10, с. 4-5. 
сил 6 мире. Израильские заправильи, состоящие на службе у империалистов Запада и подталкиваемье ими, совершили нападение на один из больших отрядов начионально-освободительного движения - Оббединенную Арабскую Республику, Сирию и другие арабские страньь. Израильское правительство, пользуясь поддержкой своих покровителей - США, Англии, Западной Германии, - бросает нагльий бызов миролюбивым государствам. Самого решительного осуждения заслуживатот действия зарвавиихся правителей Израиля на оккупированньх территориях арабских стран... Война во Вьетнаме, а 6 последнее время вероломное нападение Израиля на арабские странь с новой силой разоблачили империализм В глазах миллионов людей Европьи, Азии, Африки и Аатинской Америки. Все более растет ненависть народов к империалистическим хииникам» (Брежнев, 1970, 39, 43, 46).

Очевидно, что многие тезисы статьи М.-Х. Курбанова опирались на выступления А.И. Брежнева. Стиць, структура статьи М.-Х. Курбанова, встречающиеся в нем кцише показывают, что эта статья если не была написана советскими востоковедами, то, во всяком случае, была существенно ими отредактирована. Наличие большого числа советологизмов в тексте, многие из которых встречаются также в советских академических учебниках арабского языка, говорит нам о существенном вциянии советской востоковеАной академической школы на редакцию статей мусульманского журнала ${ }^{23}$.

В контексте ярко выраженных советологизмов в журнале «Мусульмане Советского Востока» выделяются некрологи, посвященные смерти тех ици иных религиозных деятемей.

Так, в одном из некрологов написано:

«Мусульман Советского Востока постигла большая беда: 22 декабря 1976 года в возрасте 81 года скончался исламский деятель, один из основателей СААУМ Исмаил Махдум б. Сати Ахунд из Намангана... Мусульмане Средней Азии и Казахстана навсег-

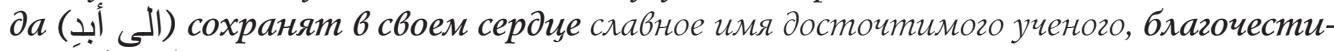
вого богобоязненного наставника шейха Исмаила Махуума, да покроет Аллах его Своей милостью и да поселит его 6 Раю» ${ }^{24}$.

В этом фрагменте обращает на себя внимание фраза «навсегда сохранят в своем сердџе». Это ярко выраженное клише из советских газет, причем некоторые фрагменты текста противоречат вопросам мусульманской догматики. В мусульманской эсхатологии человек, как и все живое, будет обращен в прах, так что никакая память в сердџе мюдей о ком бы то ни было не сохранится.

Также обращает на себя внимание другой некролог, посвященный смерти муфтия СААУМ ЗияудАина Бабаханова:

«Ауховное управление мусульман Средней Азии и Казахстана с прискорбием и глубокой печалью сообщает, что 23 декабря 1982 года, на 75 году жизни после продолжительной болезни переселился к милости Всевьшнего Аллаха Видньй мусульманский деятель, искренний бореи за мир и дружбу среди людей, председатель Ауховного управления мусульман Средней Азии и Казахстана, муфтий Зияуддин-хан б. Ииан Бабахан, да смихуется над ним Аллах. Мь принадлежим Аллаху и к Нему мы Вернемся» 25.

23. См., например: Ковалев, Шарбатов (1969).

24. Аш-Шайх Исма'им Махдум 6. Сати ахунд фи зимма ал-Хулуд (Шайх Исма‘и Махдум б. Сати ахунд в Раю) // Мусульмане Советского Востока, 1976, № 29, с. 20.

25. Факия ац-Ислам самаха аш-шайх Аийа аА-Аин Хан 6. Ишан Бабахан рахимаху Алах (Покойный, чья смерть явмяется утратой дия ислама, его священство, шайх Аийа аА-Аин Хан б. Ишан Бабахан, да смилуется наА ним Ациах) // Мусульмане Советского Востока, 1982, № 56, с. 1. 
Эта структура некролога почти полностью повторяет стиль тех некрологов, которые были посвящены смерти видных партийных деятелей, в частности $\Lambda . И$. Брежнева, который скончался месяџем ранее. Аюбопытно также обратить внимание, что портреты скончавшихся мусульманских мидеров облачены в журнале в черную траурную рамку, что вообще не характерно для мусульманской традиции. Вместе с тем советская традиция составления некрологов тесно переплетена с типично исламскими сюжетами: «пе-

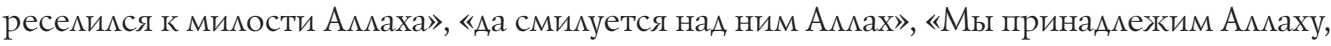
и к Нему мы вернемся».

Аругой раздел, который показывает очень сильное вАияние советских элементов и некоторый отход от мусульманской традищии, - это статьи, посвященные развитию образования в мусульманских регионах СССР.

Так, в статье «Образование в Узбекистане» нет ни слова об исламском образовании в Узбекской ССР, несмотря даже на то, что в Бухаре в этот период функционировало медресе «Мир-и Араб». Автор статьи полностью игнорирует вопрос исламского образова-

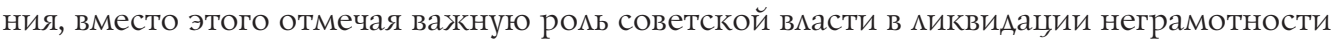
в регионах Центральной Азии:

«В 1912 г. В Узбекистане бьло 135 начальньх и 12 средних школ, где обучалось в общей сложности 17300 учашихся - детей богачей и тех, кто служил иарской России. И только 2 процента узбеков бьло грамотными. Во всем Туркестанском крае было бсего одно учебное заведение, которое готовило учителей и где обучалось в тот период 86 человек, из них только 10 бьли предстаблень местньми народностами. Такое зверское (الو حثية) отношение было характерно для иарской власти в иелом, ито привело к регрессу в области культурьи и образования Туркестана... С первьх дней установления Советской власти были осуществлень большие шаги в области ликвидачии неграмотности... В 1940-41 годах количество школ и учашихся увеличилось по сравнению с 1915-16 г2. соответственно в 70 и 71 раз. С тех пор количество икол непрерььно растет. За один 1967 год в Узбекистане было построено более 200 школ с 200 тьсячами учашихся...»².

Таким образом, в этой статье представлены сухие статистические данные, критика политики Российской империи, восхваление советской власти и нет ни слова о мусульманской этике (тарбийа, 'илм ал-ахлак) или о мусульманском образовании, что было характерно Аля досоветских и раннесоветских газет и журналов.

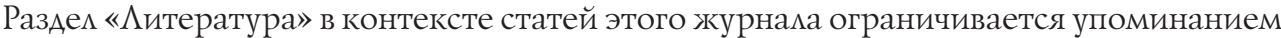
издания Корана и мусульманских календарей, а также некоторых произведений современных узбекских или таджикских поэтов, академических изданий по истории тех или иных республик Центральной Азии. Что касается мусульманской китературы, то помимо общеизвестного факта, что учебная или богословская цитература по разным жанрам мусульманской науки не издавалась, характерно высказывание по этому поводу муфтия ЗияудАина Бабаханова, который ответил на вопрос по поводу издания сочинений хадисоведа Мухаммада ал-Бухари: «Рукописей сочинений имама [ал-Бухари] у нас много, и мьь не видим необходимости в их издании. Вместе с тем, мь решили недавно издать его сочинение «ал-Адаб ал-муфрад»"

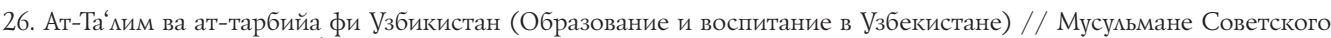
Востока, 1969, № 4, с. 25.

27. Ар-Рихла ила аА-дарих ал-Бухари (Посещение мавзолея ал-Бухари) // Мусульмане Советского Востока, 1969, № 3, c. 26. 


\section{МиРАСИзМ}

$\mathrm{B}$

журнале «Мусульмане Советского Востока» содержится немало статей, посвященных тем или иным историческим миџам - религиозным деятемям Средней Азии. Вместе с тем биографии представителей мусульманской элиты зачастую написаны в контексте «мирасизма». В рамках такого подхода советские исследователи биографий тех или иных мусульманских богословов сознательно выхолащивами и минимизироваци их религиозную деятельность, а сами эти богословы обычно представ ялись больше в культурном или научном контексте, в интерпретации их идей сквозь призму национальной истории, культуры или развития естественных наук $^{28}$.

В частности, в юбилейных статьях, посвященных таким ученым, как Абу Райхан ац-Бируни, Ал-Хорезми, Улугбек, приведена их краткая биография, а также их деятельность в области истории, математики и астрономии. При этом их религиозная деятельность и всякий исламский контекст авторами статей максимально игнорируются ${ }^{29}$. Более того, авторы статей ссылаются на авторитет советских востоковедов, которые отмечали вкцаА этих мусульманских ученых в развитие истории, математики и астрономии. В частности, в статье, посвященной Абу Райхану ац-Бируни, автор ссымается на авторитет советского арабиста и востоковеда И.Ю. Крачковского, который

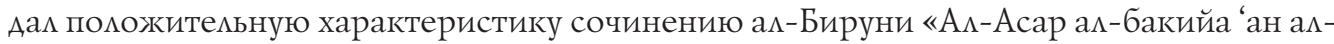
курун ац-хамийа» ${ }^{30}$.

Характерна в этом отношении статья, посвященная татарскому ученому ШихабуАдину ал-Марджани. Обращает на себя внимание, что в этой статье ал-Марджани выступает прежде всего как историк, а также как реформатор, который выступал с идеей реформы образования и введения в учебный проџесс «светских наук», призывал свой народ развивать наџиональное искусство: живопись, скульптуру и архитектуру, а также национацьную музыку.

Основной акцент статьи связан с тем, что ац-Марджани быц «свободным мыслителем», выступац против «закоснелого мышиения», за развитие национального самосознания, национацьной истории, национальной культуры и искусств. В тексте часто используются штампы и кАише, свойственные исследованиям советских историков и философов-обшествоведов в контексте мирасизма. Так, в статье пишется, что после возвращения ал-Марджани из Центральной Азии, где он обучался в Бухаре и в Самарканде, в Казани против него стали выступать представите $и$ местной мусульманской элиты с «закосневшим мышлением (التجمّد الفكرى)", препятствуя его деятельности и «обвиняя его в неверии (الكفر) и в «ереси» (زلدقرة). В статье встречаются такие кмише и речевые штампы, больше свойственные советской исторической и философской традиции, а не исламским текстам, как «пробуждение патриотизма мусумьман (اليقظة الوطنبة للمسلمين), «мыслитель (مفكرّ), «свободомыслие (حرية الفكر)». В статье отмечается роль ал-Марджани в культурном и социальном возрождении татар, пробуждении их идейного и национального самосо-

28. О мирасизме см.: Dudoignon (1996), Bustanov, Kemper (2012), Kemper (2014).

29. Зикра Аби Райхан ал-Бируни (Юбилей Абу Райхана ал-Бируни) // Мусульмане Советского Востока, 1971, № 9-10, c. 35-36; ал-Хваризми ва ал-асас ал-мантики ми кибирнитика (Ал-Хорезми и основы могики в кибернетике) // Мусульмане Советского Востока, 1972, № 12, с. 16-17; Ал-Мунаджжим ал-кабир (Великий астроном) // Мусульмане Советского Востока, 1972, № 12, с. 18-19.

30. Зикра Аби Райхан ал-Бируни // Мусульмане Советского Востока, 1971, № 9-10, с. 36. 
знания: «ал-Марджани предстает в религиозной сфере как демократ и бореч за зашиту начиональной культурь мусульман» ${ }^{31}$.

Сведения же о религиозной деятельности Шихабуддина ал-Марджани, его активной роли в исламском дискурсе Поволжья сведены к минимуму. В статье вскользь упоминается то, что ац-Марджани изучал мусульманское право и догматику и даже написал несколько работ по этим наукам. Вместе с тем основное внимание в статье уделено деятельности ац-МарАжани как педагога, историка и философа.

\section{ЗАКЛЮЧЕНИЕ}

урнал «Мусульмане Советского Востока», равно как и большая часть советской прессы, выполнял идеологическую функцию. Он представцял советский ислам и советского мусульманина в глазах советской власти. Этот взгляд на ислам и мусульман со стороны власти несколько отличался от преАставления об исламском благочестии, широко встречающемся в исламской книжной традиџии.

Анализ статей журнала «Мусульмане Советского Востока» показывает ту картину советского мусульманина, которая была «нарисована» советскими чиновниками и которая служила бы репрезентацией советского мусульманина и политики советской власти в отношении ислама на международной арене.

На основе статей журнала эту репрезентацию «советского мусульманина» можно кратко описать в следующих тезисах:

- Советский мусульманин выступает за мир во всем мире.

- Советский мусульманин - против эксплуатации человека человеком.

- Советский мусульманин стоит на страже социалистических завоеваний.

- Советский мусульманин бережно чтит свое культурное наследие.

- Советская власть гарантирует права и свободы всех граждан СССР, независимо от их национальности и вероисповедания.

- Все мусульмане СССР могут свободно исполнять свои религиозные потребности.

Если говорить о стиле изложения, то на уровне употребцяемой мексики и стилистики можно заметить очень сильное влияние советской востоковеАной школы с присущей ей системой мексики, фразеологических штампов и клише.

Официальным учредителем и издателем журнала являлось Ауховное управление мусульман Средней Азии и Казахстана, однако в статьях мы наблюдаем обилие советских идеологических клише, которые явмялись кацькой на арабский язык широко распространенных и популярных в советской общественно-политической риторике речевых штампов и оборотов. Многие статьи общественно-политического характера практически дословно по стилю и мексике Аубцируют ряд текстов советских газет, статьи Конституции СССР ици же схожи с текстами советских учебников арабского языка, написанных советскими востоковедами.

Текстологический анализ ряда статей дает нам возможность преАположить, что они если не принадлежаци полностью, то, во всяком случае, перед изданием были сушественно отредактированы советскими востоковедами, получившими образование в советских вузах. 
Вместе с тем эти советские кцише были вкцючены в текст не обособленно, а были тесно переплетены с «традиџионной» исламской письменной культурой. К примеру, в ряде некрологов язык и стиль, с оАной стороны, не отличацись от аналогичных текстов в советских газетах, с Аругой стороны, в этот же советский по своему стилю некролог часто вкцючалась традиционная мусульманская фраза: «Воистину, мы принадлежим Алмаху и к Нему возвращаемся» (Коран, 2:156.). Если из некоторых статей убрать слова «мусульмане», «ислам», и т.А. и заменить их словами «советский народ», «партия», то при переводе на русский язык полностью исчезает мусульманский контекст.

Статьи, издаваемые в журнаце «Мусульмане Советского Востока», в подавцяющем большинстве затрагивали такие сферы, как общественно-политическая и экономическая жизнь мусульманских регионов СССР, а также вопросы культуры. Сугубо исламская тематика, характерная дия досоветской и раннесоветской мусульманской прессы, в частности вопросы мусульманского права, догматики, хадисов и суфизма, в журнале практически не представлена. Вместе с тем та незначительная часть статей, посвященная некоторым исламским сюжетам в сфере богослужения и обрядовой практики, ограничена больше этическими вопросами, а также описанием празднования двух мусульманских праздников - Курбан-байрама и Ураза-байрама.

В журнале также издавацось немало статей, посвященных крупным преАставитемям исламского мира. Вместе с тем обращает на себя внимание тот факт, что био-

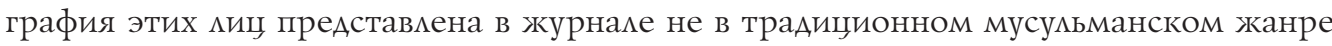
описания их биографии с перечислением их богословского наследия, теоретических вопросов мусульманского права, хадисов и прочего, а как часть культурного наследия мусульман Средней Азии, Кавказа и Поволжья. В стиле ряда статей, посвященных персоналиям, можно наблюдать перепцетение элементов как советской исторической школы, так и мусульманской традиции описания биографий. Вместе с тем в журнале зачастую нивелировался исламский контекст и при этом усиливался культурный компонент. Фотографии, вкцюченные в журнал, также Аолжны были подчеркнуть не столько исламскую составцяющую, сколько успехи советского государства в разных сферах народного хозяйства в мусульманских союзных и автономных респубциках СССР. То есть журнац служиц средством идеологического вцияния на мусульманское население СССР в контексте соџиалистических преобразований. Таким образом, журнац Аолжен бым быть репрезентаџией «правицьного» ислама, ориентированного на исторический и культурный контекст, каким его видело ици пыталось увидеть советское правительство.

Журнал «Мусульмане Советского Востока», который рассылался во многих экземпцярах по всем четырем советским муфтиятам, играц важную роль в межрегиональных связях. Исторически в досоветский период мусульмане Северо-Восточного Кавказа были тесно связаны образовательными и суфийскими сетями с мусульманами Волго-Уральского региона, а связи со Средней Азией почти отсутствовали. Вместе с тем, помимо прочих факторов (совместные конференции, обучение Аагестанцев в медресе «Мир-и Араб», общая тематика фетв, офиџиальные советские структуры), журнац способствовац налаживанию прямых контактов мусульман Аагестана и СреАней Азии.

Обращают на себя внимание и языки, на которых издавался журнал. Учитывая, что после закрытия раннесоветских мадраса прошио почти полвека и что арабский язык 
и исламские науки официально изучались только в бухарском медресе Мир-и Араб (а с 1971 г. и в Ташкентском исламском институте), мюдей, знающих арабскую графику, по цогике властей, в СССР не Аолжно было быть. Вместе с тем этот журнац выходиц на многих языках, включая английский и франџузский, за исключением русского. Этот факт является косвенным свидетельством того, что журнац «Мусульмане Советского Востока» в большей степени был рассчитан на внешнюю аудиторию - исламские и европейские страны. Вероятно, в условиях железного занавеса он служиц неким посылом Аля зарубежных мусульманских стран о поддержке советским правительством религиозных общин и как следствие - некой попыткой цегитимаџии СССР в ее внутренней религиозной политике.

\section{ПРИЛОЖЕНИЕ}

Названия статей журнала «Мусульмане Советского Востока» и краткая аннотация некоторьхх из них.

\section{№ 2, 1969 2.}

1. 25 мет СААУМ.

2. Имам Абу Ханифа.

3. Ваш счастливый праздник. [О месяце Рамадан и празднике «'ИА ац-фитр».]

4. Важный призыв. [О Аенине и Советском государстве, благах, что дало советское государство мусульманскому Востоку.]

5. Конференция ученых в Каире (университете А^-Азхар). [О необходимости адаптировать религиозную жизнь к современным реалиям. Критика США и Израимя.]

6. Юбимей Самарканда.

7. Мусульмане Северного Кавказа. [Развитие народного хозяйства и промышиенности в республиках Северного Кавказа.]

8. Юбимей города Семипалатинск.

9. Юбимей А^ишера Навои и его празднование в Узбекистане. [Конференция, посвященная Навои, и выступления русских советских поэтов и писателей.]

10. Аорогие гости из Сирии. [О приезде делегации во главе с муфтием Ахмадом Кафтару; его речь с критикой политики США и Израиля; благодарность СССР за приглашение и подАержку арабского народа против израильской агрессии.]

11. Краткие новости. [Поступиение 30 студентов в Мир Араб; посещение СССР Аелегацией из Гамбии; посешение делегацией из королевства Афганистан; о строительстве метро в Ташкенте; о проведении ирригационной системы в одной из областей Таджикистана; о городе Зарафшан и заводе по добыче золота; об издании первого из десятитомников книги в "доме знаний» в Ташкенте; о возведении (рытье) канала в Фергане; празднование «недели узбекской культуры и китературы» в Таджикистане и дружбе между таджикским и узбекским народами; продажа Узбекистаном государству 4 млн 100 тыс. тонн хлопка; проведение в Ташкенте фестиваця кино стран Азии и Африки.] 
№ 3, 1969 2.

1. 25 мет СААУМ. [История СААУМ.]

2. Промышленность в Узбекистане.

3. Свобода совести. [Статья посвящена 100-летию со дня рождения В.И. Аенина; восхваление советской власти.]

4. Мир Араб. [История медресе Мир Араб.]

5. Празднование ' $И_{\mathrm{A}}$ ал-Адха.

6. Поездка в хадж. [Советские мусульмане в хадже; повествование о той заботе, которую оказывает советское правительство мусульманам, и благодарность советскому правительству за эту заботу; критика империалистической агрессии Израиля.]

7. Имам Шафии. [Биография.]

8. Посещение мавзолея ал-Бухари. [Совместное посещение членов СААУМ и представитекей Сирии могилы имама ак-Бухари близ Самарканда.]

9. Нам пишут наши гости. [Письма зарубежной делегации, посетившей СССР в СААУМ; критика британского и американского империацизма.]

10. Комментарии к изданию журнала. [Отзывы разных читателей; поздравление с изданием журнала.]

11. Краткие новости. [Из 16 новостей всего 3 посвящены исламу: издание Корана, издание календаря по хиджре, собрание в СААУМ и отчет паломников. Остальные статьи посвящены следующим вопросам: строительство заводов и фабрик в мусульманских регионах СССР; празднование юбилея Хамзы Хаким

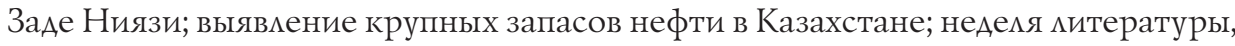
издание сборника стихов современных узбекских поэтов и издание Истории Узбекистана.]

\section{№ 4, 1969 2.}

1. Заявмение СААУМ по случаю сожжения мечети «Ац-Акса».

2. Издание Корана.

3. Блистательная мечеть. [История города Ходжанд и строительства мечети в этом городе.]

4. Конференция Мира. [О проведении конференции, посвященной миру и сотрудничеству, с приглашением представителей разных религий.]

5. Узбекистан приветствует гостей конференции. [О приеме делегатов конференции в Ташкенте.]

6. Празднование дня рождения пророка Мухаммада. [О праздновании мавлида в Ташкенте; критика израильской агрессии против жителей Палестины; посещение гостями мавзолеев имама ал-Бухари, а также Аругих мусульманских памятников Узбекистана.]

7. Образование и воспитание в Узбекистане. [Сравнение уровня образования в Узбекистане до и после установления советской власти.] 
8. Казахстан сегодня. [Развитие промышленности, сельского хозяйства, медицины и здравоохранения в Казахстане; критика имперского периода в истории Казахстана.]

9. Краткие новости. [Посещение СААУМ арабскими студентами, которые обучаются в вузах Москвы; посещение СААУМ делегацией иорданских парламентариев; посещение СААУМ демегацией парламентариев из Мавритании.]

10. Новости культуры и экономики.

\section{№ 9-10, 1971 2.}

1. Приветственное слово на конференции муфтия Закавказского АУМ Али Ага Сумейман Заде.

2. АокмаА муфтия Курбанова М. «Борьба с империалистической агрессией на арабском Востоке и в Юго-Восточной Азии».

3. Аокмад Газанфара Мир Али, имама-хатиба мечети Куюк-чай в Азербайджане «ЕАинство и сотрудничество мусульман в борьбе на пути мира против империализма и расизма и на пути к общественному прогрессу в свете учений Корана, хадисов и общественных законов».

4. Стихи, посвященные Ташкенту.

5. Женщина в исламе. [О гендерном равноправии в исламе и о важной роли соџиалистического строя в предоставлении женщинам прав.]

6. Начало сотрудничества в исламе. [Критика капиталистического строя и восхваление соџиалистического строя, советского правительства, которое защищает интересы трудового народа; критика индивидуализма; соџиализм как колмективный строй.]

7. ОАна из Аиковинок мира. [О рытье канала и орошении земель в советский период; успехи СССР в области семьского хозяйства.]

8. БАагословенное путешествие. [Рассказ одного из паломников о посещении Мекки и Медины.]

9. Мир вам. [О Аружбе между мюдьми.]

10. Крупный имам рассказывает о Советском Союзе. [Интервью с египетским богословом, первым шейхом А^-Азхара о Советском Союзе.]

11. Памяти Абу Райхана ац-Бируни.

12. Советская религиозная делегация в Каире. [О поездке делегации мусульман СССР в Каир.]

13. Письма читателей. [В.И. Аенин, его критика капитацизма и призыв к арабам освободиться от ига капитализма.]

14. Краткие новости. [Посещение советской делегащией Республики ЧаА; о строительстве электростанџий в республиках Средней Азии; Узбекистан в СССР вышел на второе место по производству ткани; исследование казахскими химиками кирпичей, из которых был сложен мавзолей Авух казахских ханов.] 


\section{№ 13, 1972 2.}

1. Ежегодная религиозная жизнь. [Отчетное собрание СААУМ.]

2. ЕАинство - благословение Аля мюдей. [О Аружбе народов, об успехах СССР в развитии разных сфер народного хозяйства; критика имперского периода в истории Центральной Азии.]

3. Посещение исламской демегаџией из СССР Фициппин и Цейлона.

4. Метро Ташкента.

5. Ац-Хорезми и основы могики в кибернетике.

6. Вемикий астроном. [Об Уиугбеке.]

7. Свобода совести и права граждан Советского Союза.

8. Мечети на берегу реки Сейхун. [Исторический и культурологический аспекты; развитие промышиенности в Туркестане в советский период; помощь, оказанная В.И. Аениным в развитии Туркестана в 1918 г.]

9. Краткие новости. [Об основании в Ташкенте Института путей сообщения, который явмяется сороковым вузом в Узбекской ССР; о начале строительства водного канала в Казахстане; о реставрации памятников архитектуры в Узбекской CCP.]

\section{№ 17,1973 2.}

1. Мусульмане Азербайджана. [Об успехах в области промышиенности, сельского хозяйства и образования в Азербайджанской ССР; о Ауховном управлении мусульман Закавказья, о единении суннитов и шиитов.]

2. Старинная мечеть в Бишкеке. [Пишпек, позже был переименован в г. Фрунзе, Ао революции представлял собой маленький город. После Октябрьской революции этот город стал стремительно развиваться и стац столицей Киргизии. О мечети им. Ицьяса-хаджи в г. Фрунзе.]

3. Размышиения возме Каабы. [Имам-хатиб мечети Коканда делится своими впечатмениями от паломничества.]

4. Шихаб аА-Аин ац-Марджани. [Статья, посвященная биографии татарского ученого Шихаб аА-Аина ал-Марджани.]

5. Первый академик Узбекистана. [О первом академике из Узбекской ССР Абиде Садыкове.]

6. Башкиры в прошлом и в настоящем. [О развитии промышленности, сельского хозяйства, зАравоохранения и образования в Башкирской АССР; об основании Оренбургского магометанского духовного собрания в XVIII веке и о АУMEC.]

7. Развитие здравоохранения в Узбекистане.

8. Абу Райхан ал-Бируни. [Биография; ал-Бируни как историк, филолог и математик.]

9. Краткие новости. [Посещение иностранными гостями СААУМ; основание в Узбекской ССР комитета культурных связей; возрастающее значение роли Узбекской ССР во внешней торговле; об электрификации межАу городами Ташкент и Чимкент; отзыв французского исследователя о государственной библиотеке Таджикской ССР; выставка достижений культуры в Нукусе, 
столице Каракалпакской АССР; об отдыхе трудящихся трех республик: Киргизской, Казахской и Узбекской в мечебных пансионатах возме озера Иссык-Куль.]

\section{№№ 18-20, 1973 2.}

Номер журнала посвящен выступлениям делегатов международной конференции «Мусульмане Советского Союза», проводимой в Ташкенте.

\section{№ 21, 19742.}

1. Великий мухадАис имам Бухари. [Биография имама Бухари.]

2. Степень набожности в жизни имама Бухари.

3. Мусульмане празднуют ' $\bigwedge_{A}$ ал-Адха.

4. Празднование выпускников медресе Мир Араб в Бухаре.

5. Посещение муфтием Зияудаином Бабахановым мечетей Ферганы.

6. Меня радует новая жизнь в кишлаке. [Раздел называется «Мусульмане в строительстве нового общества», и в него входят две статьи: 6 и 7. Аанная статья преАставляет собой письмо читателя, жителя кишлака Кыркбаш. Он пишет о бедственном положении крестьян до револющии, когда земля и водные ресурсы находицись в руках экспиуататоров, а жители кишиака жици в плохих глиняных домах. После установцения советской вцасти сельчане получили землю, а государство построило колхозникам большие и просторные Аома.]

7. С помощью Алмаха. [Аналогичная статья, где некий тракторист из Башкирии пишет о своей жизни, критикует дореволюционный период и на своем примере рассказывает о благах, которые мусульманам СССР предоставияа советская власть.]

8. Наше культурное наследие. О [сочинении] «ас-Сайдана» ал-Бируни.

9. Зарубежные связи мусульман. Посещение духовенством (риджал аА-дин) Пакистана Советского Союза.

10. Посещение Советского Союза мусульманской молодежью из Египта.

11. Посещение Советского Союза мусульманами Сингапура.

12. Ради истины. [Об успехах мусульман Средней Азиии в области сельского хозяйства и промышиенности.]

13. Краткие новости. [О количестве студентов, обучающихся в вузах Узбекской ССР; об обсерватории в Ташкенте и роли СССР в оснащении этой обсерватории современными аппаратами; о профессоре медицины, узбекском докторе Вали Меджидове; об экспорте узбекского хлопка; об электрификаџии в Туркменской ССР; о реставраџии старинной башни в Киргизской ССР; об открытии Института математики в Академии Наук Таджикской ССР; о завершении работы по составлению каталога восточных рукописей колцективом Аенинградского отделения института Востоковедения.] 
№ 26, 1975 2.

1. Ислам и борьба за мир.

2. Тридцатая годовщина победы над фашизмом.

3. Священная годовщина. [О мусульманах СССР - участниках ВОВ.]

4. Я говорю: «Нет войне». [Воспоминания мусульманина - участника ВОВ.]

5. Откцик из заграниџы. [Секретарь всемирной исламской циги Мухаммад Салих ац-Каззаз делится своими впечатлениями о международной конференции, прошедшей в августе 1974 г. в Самарканде.]

6. Развитие национальной культуры таджиков.

7. ОАна из Аревнейших рукописей Ташкента.

8. Мечеть Мешхеди Ага (в Азербайджане). [О тесной дружбе между суннитами и шиитами Азербайджанской ССР, все они вместе молятся в одной мечети.]

9. 90 мет со дня рождения. Юбилей муфтия Закавказья Али Ага Сулейман Заде.

10. Краткие новости. [О новом исследовательском центре физиологии в Узбекской ССР; о строительстве на реке Амударья нового моста, который связывает СССР с Афганистаном; о строительстве новых школ, больниц, заводов и т.А.]

\section{№ 29, 1976 2.}

1. Сияа дружбы и братства. [Ислам- миролюбивая религия, граждане СССР стоят на страже мира и дружбы межАу мюдьми.]

2. Почитание законов Корана и сунны в мечетях советского Востока. [О важной роли мечетей как интемлектуальных и культурных центров.]

3. Паломничество к святыням.

4. Посещение делегаџией советского духовенства (риджал аА-дин) демократической республики Сомали и Мавритании.

5. Узбекский язык - язык науки и культуры.

6. Символ великого признания. [О награждении орденом муфтия Закавказья Али Ага Сулейман Заде.]

7. Возвышенное послание - это служение Ациаху. [Статья о Ахмадхане 6. Азизходжа из Намангана, который закончиц Ташкентский исламский институт и был отправлен имамом мечети в свой родной город.]

8. Аревний, но современный. [История города Хорезм.]

9. Некролог по случаю смерти одного из основателей СААУМ Исмаила Махдума 6. Сати Ахунд из Намангана. 


\section{БИБЛИОГРАФИЯ}

Bustanov, A.K., Kemper, M. (2012). From Mirasism to Euro-Islam: The Translation of Islamic Legal Debates into Tatar Secular Cultural Heritage, in: A.K. Bustanov, M. Kemper (eds.), Islamic Authority and the Russian Language: Studies on Texts from European Russia, the North Caucasus and West Siberia. Amsterdam, 29-54.

Dudoignon, S.A. (1996) Djadidisme, mirasisme, islamisme. Cahiers du Monde russe (vol. XXXVI (1-2), 13-40.

Gould, R., Shikhaliev, Sh. (2017a). A Tale of Two Scholars: Daghestan Modernists in Early Twentieth Century Egypt. Retrieved from https://ssrn.com/abstract=2995762

Gould, R., Shikhaliev, Sh. (2017b). Beyond the Taqlīd/Ijtihād Dichotomy: Daghestani Legal Thought under Russian Rule, in: Islamic Law and Society, Vol. 24, 142-169.

Kemper, M. (2014). Ijtihad into philosophy: Islam as cultural heritage in post-Stalinist Daghestan. Central Asian Survey. Vol.33, Issue 3. 390-404.

Kemper, M., Shikhaliev, Sh. (2015). Qadimism and Jadidism in Twentieth-Century Daghestan // Asiatische Studien - Études Asiatiques. Vol. 69, Issue 3, 593-624.

Акаев, А. (1992). Тиц масъаласы / / Оразаев Г.М.-Р. (сост.). Пайхаммарны ёлу булан (Тропою Пророка). Махачкала, с. 75-84.

А^-Гумуки, А. (1917). Мас’ала куга ат-та' иим // Ажаридат Аагистан. № 23-24.

Ал-Ажам'иййа аА-диниййа фи ац-джумхуриййа ал-Адигиййа (1927, № 8, август). Байан ал-хакаик, с. 14-16.

Арапов А.Ю. (2010). Ислам и советское государство (1917-1936). Сборник Аокументов. Вып. 2. М: ИзАательский дом «МарАжани».

Байан ац-хака'ик. (1925, сентябрь). Буйнакск.

Брежнев А.И. (1970). Речь на приеме в Кремле в честь выпускников военных академий 5 июля 1967 г. // Брежнев А.И. Аенинским курсом. Речи и статьи. Том 2. Москва.

Каяев А. (1993). Аве разные ориентации // Меджидов Ю.В., АбАумлаев М.А. Али Каяев: очерки жизни и творчества. Махачкала, с. 360-366.

Ковалев А.А., Шарбатов Г.Ш. (1969). Учебник арабского языка. Москва.

Наврузов А.Р. (2012). «Ажаридат Аагистан» - арабоязычная газета кавказских джадиАов. М., «Марджани».

Сулаев И.Х. (2009). Государство и мусульманское духовенство в Аагестане: история взаимоотношений (1917-1991). Махачкала.

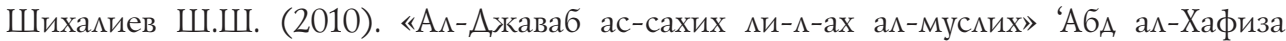
Охлинского // Аагестан и мусульманский Восток. Сборник статей / сост. и отв. реА. А.К. Аликберов, В.О. Бобровников. М.: «Марджани».

Шихалиев Ш.Ш. (2017). Мусульманское реформаторство в Аагестане (1900-1930) // Государство, религия, церковь в России и за рубежом. М.: «РАНХиГС», № 3 (35), с. 134-169.

Шихсаидов, А.Р. (1984). Эпиграфические памятники Аагестана как исторический источник. Москва. 